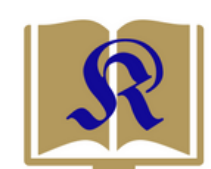

KURIOS

\title{
Pendidikan Anak dalam Keluarga Berdasarkan Kolose 3:21
}

\author{
Ezra Tari $^{1}$, Talizaro Tafonao ${ }^{2}$ \\ ${ }^{1}$ Sekolah Tinggi Agama Kristen Negeri Kupang \\ ${ }^{2}$ Sekolah Tinggi Teologi Kadesi, Yogyakarta \\ ${ }^{1}$ tariezra@gmail.com, ${ }^{2}$ talizarotafonao@gmail.com
}

\section{Abstract}

This article aimed to describe the education of children in the family based on Colossians 3:21. This study used a sociological criticism approach by conducting a study of the text of Colossians 3:21 to analyze the Bible's view of children's education in the family. The conclusion of this textual study is educating children without violence. Paul reminded fathers in educating children to prioritize love as the basis for education in the family. The love of a father will be reflected in the lives of every child through communication and imprinted in an attitude of obedience and respect for parents.

\begin{abstract}
Abstrak
Artikel ini bertujuan untuk mendreskripsikan pendidikan anak dalam keluarga berdasarkan Kolose 3:21. Penelitian ini menggunakan metode pendekatan kritik sosiologis dengan melakukan kajian terhadap teks Kolose 3:21untuk menganalisis pandangan Alkitab tentang pendidikan anak dalam keluarga. Kesimpulan dalam kajian terhadap teks tersebut adalah mendidik anak tanpa adanya kekerasan. Paulus mengingatkan para ayah dalam mendidik anak-anak lebih mengutamakan kasih sayang sebagai dasar pendidikan dalam keluarga. Kasih sayang seorang ayah akan tercermin dalam kehidupan setiap anak melalui komunikasi dan terpatri dalam sikap taat dan menghormati orang tua.
\end{abstract}

Article History

Submit:

13 March 2019

Revised:

18 April 2019

Accepted:

25 April 2019

Keywords

(kata kunci):

children

education;

Colossians 3; education; family; anak; keluarga;

Kolose 3; pendidikan anak

\section{Pendahuluan}

Keluarga adalah salah satu kumpulan orang-orang yang hidup bersama yang memiliki hubungan darah atau ikatan perkawinan, seperti ayah, ibu dan anak. Menurut Kamus Besar Bahasa Indonesia keluarga adalah kelompok terkecil dari masyarakat. Setiap anggota dalam keluarga memiliki ikatan yang sangat kuat, bahkan disebut sebagai kerabatan yang sangat mendasar di masyarakat. ${ }^{1}$ Lembaga keluarga memiliki fungsi pokok utama yakni memenuhi kebutuhan biologis, emosional, sosial ekonomi dan pendidikan. Dari sekian fungsi tersebut, fokus kajian ini adalah pada bagian pendidikan. Sejatinya, pendidikan dimulai dari dalam keluarga karena tidak ada orang yang tidak dilahirkan dalam keluarga. Jauh sebelum ada

\footnotetext{
${ }^{1}$ Departemen Pendidikan Nasional, Kamus Besar Indonesia (Jakarta: Balai Pustaka, 1990), 536.
} 
lembaga pendidikan yang disebut sekolah, keluarga telah ada sebagai lembaga yang memainkan peran penting dalam pendidikan yakni sebagai peletak dasar. Sebab pendidikan dalam keluarga memiliki pengaruh yang kuat dalam membentuk sikap, emosi dan perilaku positif.

Menurut Sofia Retnowati dan Wahyu Widhiarso kehidupan keluarga merupakan tempat anak belajar pertama kali dalam mempelajari emosi, berupa bagaimana mengenal emosi, merasakan emosi, menanggapi situasi yang menimbulkan emosi serta mengungkapkan emosi. Melalui wadah penggodokan keluarga, individu belajar mengungkapkan emosinya. Individu melakukan tindakan seperti apa yang didemonstrasikan orang tuanya ketika mengasuhnya dengan mengungkapkan emosinya secara verbal maupun secara non verbal. ${ }^{2}$ Namun dalam realitanya pendidikan dalam keluarga sering kali tidak berjalan sesui dengan harapan, bahkan pendidikan itu sendiri cenderung menjadi nomor sekian dalam keluarga. Ada beberapa alasan mengapa orangtua kurang memperhatikan pendidikan anak dalam keluarga, yakni: orangtua tidak berpendidikan, orangtua terlalu sibuk dengan pekerjaannya, orangtua kurang kesadaran terhadap pendidikan, orangtua tidak ada keharmonisan dalam kelaurga, dan orangtua menghadapi kondisi ekonomi yang kurang mendukung.

Berdasarkan penjelasan itu di atas, maka dapat disimpulkan bahwa sampai detik ini, masih banyak orang tua yang kurang memperhatikan pentingnya pendidikan anak dalam keluarga. Akibatnya ada banyak anak-anak yang terjerumus pada kehidupan pergaulan bebas. Pergaulan bebas adalah salah satu bentuk prilaku menyimpang yang mana "bebas" yang dimaksud adalah melewati batas norma-norma. ${ }^{3}$ Pergaulan bebas adalah prilaku manusia yang menyimpang yang melanggar norma-norma agama dan tidak ada batasannya. Menurut hemat Hurlock mengatakan bahwa bobroknya moral seorang anak dan remaja bisa diakibatkan salah satu kesalahan dari orangtuanya seperti dalam hal mendidik anak terlalu keras, keluarga yang sedang bermasalah (broken home), di mana hal tersebut dapat membuat anak menjadi orang yang temperamental. ${ }^{4}$

Dalam era modernisasi sekarang ini, peran orang tua sangat dibutuhkan. Berkenaan dengan perkembangan kecanggihan teknologi. Sesuatu yang tidak dapat dihindari bahwa teknologi berkembang dengan pesat sehingga penggunaannya banyak digunakan tidak semestinya. Oleh karena itu, Sitti Nadirah menghimbau, agar keluarga yang ada hendaknya mempunyai peranan penting dalam membentuk perkembangan, kepribadian dan sebagai pengontrol bagi anak-anak (remaja) untuk dapat memberikan batasan-batasan dalam menjalani kehidupan sosial serta tempat pendidikan bagi remaja dalam menghadapai masuknya kehidupan modernisasi saat ini. ${ }^{5}$

\footnotetext{
${ }^{2}$ Sofia Retnowati and Wahyu Widhiarso, "Peranan Keberfungsian Keluarga Pada Pemahaman Dan Pengungkapan Emosi," Jurnal Psikologi, no. 2 (2003): 91 - 104.

${ }^{3}$ Sitti Nadirah, "Peranan Pendidikan Dalam Menghindari Pergaulan Bebas Anak Usia Remaja," Musawa 9 , no. 2 (2017).

${ }^{4}$ Elizabeth Hurlock, Perkembangan Anak (Jakarta: Erlangga, 1978), 25.

${ }^{5}$ Sitti Nadirah, "Peranan Pendidikan Dalam Menghindari Pergaulan Bebas Anak Usia Remaja."
} 
Selain penjelasan di atas, ada beberapa faktor penyebab terjadinya kenakalan anak dalam keluarga, yakni: Keluarga tidak harmonis, kurangnya kasih sayang, pendidikan yang terlalu keras, komunikasi yang buruk, lingkungan pergaulan yang salah, pengaruh kemajuan teknologi. Oleh karena itu, peran orangtua dalam mendidik anak sangat penting karena orang tua adalah tempat pertama bagi anak untuk mendapatkan pendidikan sebelum mendapatkan pendidikan di sekolah. Sudah waktunya orangtua berhenti berdalih dalam mendidik anakanaknya termasuk mengharapkan gereja atau sekolah. Lembaga-lambaga yang ada sangat terbatas dalam menggantikan posisi orangtua.

Pola pendidikan anak dalam keluarga tergantung budaya yang dianut orang tua. Cara mendidik anak tergantung kearifan lokal yang dimiliki oleh setiap daerah. ${ }^{6}$ Sekalipun demikian, ada dua metode penting yang digunakan oleh orangtua dalam mendidik anak di lingkungan keluarga, yakni pertama pembiasaan dan keteladanan agar terpatri dalam diri anak. Yang kedua latihan dan praktikum, agar anak dapat melakukan amaliah keagamaan sesuai dengan tuntutan yang telah ditetapkan agama. ${ }^{7}$ Dengan kata lain, seorang anak mendapatkan pemahaman tentang kehendak Allah dari pengajaran orang tuanya. Di dalam keluarga Kristen tidak tepat beranggapan bahwa tugas orang tua bertentangan dengan tugas Allah (bnd.Luk 14:26). ${ }^{8}$

Untuk itu, ada empat tahap dalam komunikasi antar pribadi, yaitu: pertama, kontak, tahap pertama kita melakukan kontak. Seperti bersinggungan masalah fisik. Ada beberapa hal yang berkaitan mengenai alat indera seperti melihat, mendengar, merasa, mencium, dan sebagainya. Kedua, keterlibatan, keluarga tentu memiliki hubungan yang erat pada setiap anggota keluarga. Hubungan tersebut membuat antara anggota keluarga satu dengan yang lain memiliki keterikatan yang sangat erat. Ketiga, keakraban, pada tahap setiap orang mengikat diri dengan orang lain lebih jauh. Seseorang memungkinkan untuk membina hubungan primer dimana orang lain menjadi sahabat baik atau kekasih. Komitmen ini dapat membantu orang tersebut secara moril atau matril. Keempat, perusakan, tahap ini merupakan penurunan hubungan. Pada tahap ini, orang mungkin merasa bahwa hubungan ini tidaklah sepenting yang dipikirkan sebelumnya.

Oleh karena itu, keadaan kehidupan keluarga bagi seorang anak dapat dirasakan melalui sikap dari orang yang sangat dekat dan berarti baginya. Perilaku agresif merupakan salah satu bentuk respon negatif yang timbul akibat dari strategi dalam pemecahan masalah yang kurang

\footnotetext{
${ }^{6}$ Novie D S Pasuhuk, "Pendidikan Keluarga Yang Efektif," KURIOS (Jurnal Teologi dan Pendidikan Agama Kristen) 2, no. 1 (2014): 70-81, www.sttpb.ac.id/e-journal/index.php/kurios. Band: Susi Rio Panjaitan, "Teologi Anak Sebuah Kajian," in Anak Bersinar Bangsa Gemilang Jaringan Peduli Anaka Bangsa (Jakarta: Perkantas, 2018), 75.

${ }^{7}$ Vitaurus Hendra, "Peran Orang Tua Dalam Menerapkan Kasih Dan Disiplin Kepada Anak Usia 2-6 Tahun Sebagai Upaya Pembentukkan Karakter," KURIOS (Jurnal Teologi dan Pendidikan Agama Kristen) 3, no. 1 (2015): 48-65, www.sttpb.ac.id/e-journal/index.php/kurios.

${ }^{8}$ Charles E. Pfeiffer and Everett F Harrison, The Wycliffe Bible Comentary (Tafsiran Alkitab Wycliffe) (Malang: Gandum Mas, 2001), 815.
} 
tepat, perilaku agresif yang sering terjadi diantaranya agresif fisik, verbal dan destruktif (perkelahian, penganiayaan, dan lain-lain). ${ }^{9}$

Maka daripada itu, dalam menghadapi anak-anak yang bermasalah sebaiknya orang tua mengkedepankan rasa kasih sayang dan penuh kehangatan. Rasa sayang akan lebihefektif ketika orangtua tidak hanya menerima anaknya, tetapi juga menerima keadaan dirinya sendiri. Orang tua bisa menjadi lebih bijak dalam melakukan penerimaan, jika orang tua bisa menjalankan hidup lebih realistis. ${ }^{10}$ Pada budaya timur seperti Indonesia, peran pengasuhan lebih banyak dipegang oleh istri atau ibu, meskipun mendidik anak merupakan tanggung jawab bersama. Pola asuh adalah gambaran yang dipakai oleh orangtua untuk mengasuh (merawat, menjaga, atau mendidik) anak. Bentuk pola asuh orang tua terhadap anak terdiri dari pola asuh demokratis, pola asuh otoriter, pola asuh permisif memanjakan, dan pola asuh permisif penelantaran. Perkembangan anak prasekolah meliputi perkembangan motorik kasar, motorik halus, sosial kemandirian, dan perkembangan bahasa.Perkembangan bahasa adalah kemampuan untuk memberikan respon terhadap suara, mengikuti perintah dan berbicara spontan. $^{11}$

Hasil penelitian yang dilakukan oleh Maria Lidya Wenas dan I Putu Ayub Darmawan, memberikan beberapa kesimpulan penting dari Pendidikan Anak yaitu: Pertama, Ayat-ayat Alkitab berbicara tentang pentingnya pendidikan anak. Dalam Perjanjian Lama kitab Keluaran, Ulangan, dan Mazmur memberikan penekanan tentang pendidikan anak. Dalam Perjanjian Baru, Yesus Kristus menaruh sebuah perhatian penting bagi anak-anak. Demikian pula dalam surat-surat Paulus, Efesus dan Kolose, ada sebuah perhatian terhadap anak dan pendidikan anak. Kedua, Dalam perspektif Alkitab ada tiga prinsip penting yang dapat diperoleh yaitu (1) pendidikan anak merupakan sebuah proses penanaman iman; (2) pendidikan anak merupakan sebuah proses transfer pengetahuan; dan (3) pendidikan adalah sebuah proses penanaman nilai-nilai kekristenan. ${ }^{12}$

\section{Metodologi}

Artikel ini memuat sebuah kajian yang menggunakan pendekatan kritik sosiologis. Menurut M Robert Mulholland menekankan dasar kritik sosiologi sebagai berikut: Pertama, peneliti mengkaji pada mulanya tentang kedudukan sosial dari dunia Perjanjian Baru yaitu secara deskriptif, penentuan teks arkeologi dan prasasti menyangkut politik, ekonomi, kebudayaan, agama, kemasyarakatan, pendidikan dan struktur paguyuban dalam masa Perjanjian Baru. Kedua, lebih analitis; ialah deskripsi dinamika sosiologi dari dunia Perjanjian Baru, pemahaman interaksi antara struktur sosial yang beranekaragam (perkembangan,

\footnotetext{
${ }^{9}$ Selistia Minarni, "Hubungan Antara Komunikasi Interpersonal Orang Tua Dengan Perilaku Agresif Pada Remaja Anggota Geng Di Samarinda," Psikoborneo 5, no. 2 (2017): 301-309.

${ }^{10}$ Ika Suwaji and Yamin Setiawan, "Hubungan Penerimaan Orang Tua Dan Konsep Diri Dengan Motivasi Berprestasi Pada Anak Slowlearner,” Jurnal Psikologi Indonesia 3, no. 3 (2014): 238-288.

${ }^{11}$ Zuraida Mulqiah, Eka Santi, and Dhian Ririn Lestari, "Pola Asuh Orang Tua Dengan Perkembangan Bahasa Anak Prasekolah (Usia 3-6 Tahun),” Dunia Keperawatan 5, no. 1 (2017): 61-67.

${ }^{12}$ Maria Lidya Wenas and I Putu Ayub Darmawan, "Signifikansi Pendidikan Anak Dalam Perspektif Alkitab," Evangelikal: Jurnal Teologi Injili dan Pembinaan Warga Jemaat 1, no. 2 (2017), http://journal.sttsimpson.ac.id/index.php/EJTI.
} 
kemunduran, munculnya struktur sosial yang baru). Ketiga, keduanya secara deskriptif dan analisis ialah penggunaan model sosiologi dalam membantu si peneliti menetukan dan menganalisis jalan di mana kelompok dan pribadi timbul dan berfungsi dalam matriks sosiologi dari lingkungan yang beraneka segi. Keempat, sebagai bagian dari proses mendatang untuk beberapa pegangan matriks sosial Perjanjian Baru dan dinamika gerakan kristen dalam matriks, teks Perjanjian Baru dipelajari dalam konteks sosiologi persekutuan Kristen dalam dunia romawi pada abad pertama. Kelima, melalui semua proses kritik sosiologi harus diawasi dengan teliti perbedaan antara horison sosiologi dari penafsir dengan teks. ${ }^{13}$

Selain itu, kajian ini menggunakan analisis deskriptif terhdap teks Kolose 3:21. Analisis teks ditunjukkan oleh diagram eksegesis di bawah ini yang menggunakan teks Yunani dari

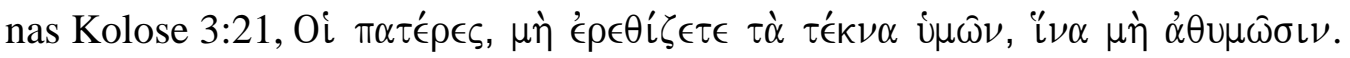

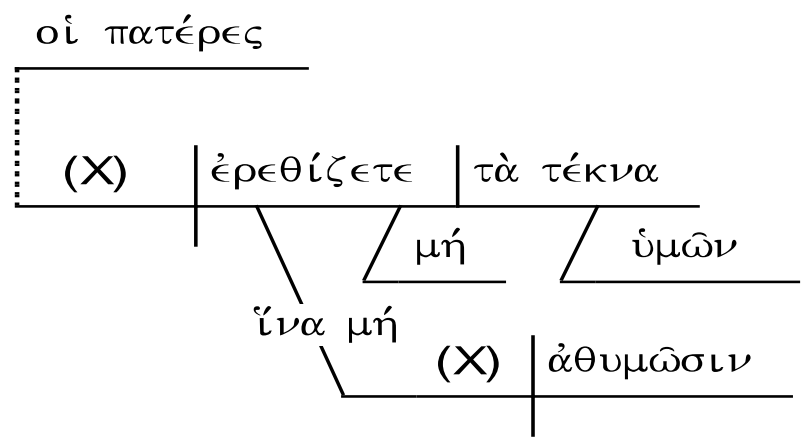

Diagram Ekesegesis Kolose 3:21

Artikel Oı'(hoi) definite article nominative yang merupakan bentuk plural dari ò (ho) as

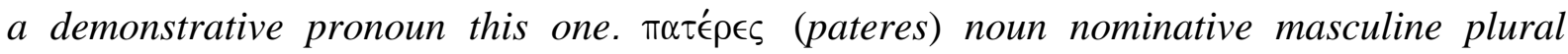
common from $\pi \alpha \tau \eta \dot{\rho}$ (pater). Kata benda maskulin jamak umum dari Pather, artinya bapa, orang tua. $\mu \eta ́$ (me) negative particle not, kata negatif tidak, bukan. '́ $\rho \in \theta^{\prime} \zeta \epsilon \tau \epsilon$ (epethizete) verb imperative present active 2 nd person plural from ' $\epsilon \rho \in \theta^{\prime} \zeta \omega \nu$ (epithizon). ' $€ \rho \in \theta \dot{\imath} \zeta \omega$ (epithizo) menimbulkan atau membangkitkan, menimbulkan dalam pengertian baik. $\tau \dot{\alpha}$ (ta) definite article accusative neuter plural from ò (ho), as a demonstrative pronoun this one, that one,

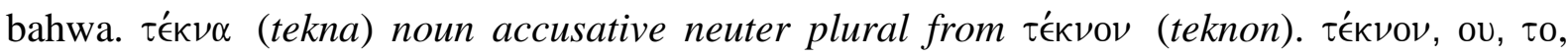

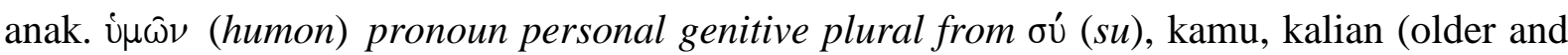
more formal sing). ¿ $\nu \alpha$ (hina) kata penghubung. $\mu \eta \dot{~(m e) ~ n e g a t i v e ~ p a r t i c l e ~ n o t, ~ k a t a ~ n e g a t i f ~}$ tidak, atau bukan. $\dot{\alpha} \theta \mathrm{v} \mu \omega \sigma \mathrm{\nu} \nu$ (athumosin), verb subjunctive present active third person plural from $\dot{\alpha} \theta u \mu \mu^{\prime} \omega$ (athumeo). $\dot{\alpha} \theta u \mu \epsilon \epsilon$ (athumeo) menakut-nakuti, kehilangan semangat. ${ }^{14}$

Berdasarkan diagram di atas dapat diterjemahkan: Bapa-bapa menimbulkan yang baik bukan menyakiti anak kamu, tidak kehilangan semangat. Terjemahan Indonesia sederhana: Hai bapak-bapak, janganlah sakiti hati anakmu, supaya jangan tawar hatinya. Terjemahan

\footnotetext{
${ }^{13}$ A.A. Sitompul and Ulrich Beyer, Metode Penafsiran Alkitab (Jakarta: BPK Gunung Mulia, 2009), 214.

${ }^{14}$ Word Analysis, "Bible Works" (Norfolk, 2006).
} 
King James Version: Fathers, provoke not your children to anger, lest they be discouraged. Peringatan Paulus pada keluarga (ay.18-4:1) menunjukkan bagaimana kehidupan baru orang percaya dalam Kristus harus memengaruhi setiap bidang kehidupan. Bukti perubahannya adalah bahwa kita tidak lagi hidup untukdiri sendiri, tetapi untuk orang lain (lih. I Yoh 3:16). Ini mengemulasi kehidupan Yesus.Orientasi yangbenar-benar baru ini adalah bukti bahwa kita telah ditebus.

Teks Kolose 3:21 yang berbunyi: "Hai bapa-bapa, janganlah sakiti hati anakmu," merupakan bentuk present active, imperative dengan negative. Unsur yang berarti menghentikan suatu tindakan dalam proses, "berhenti menjengkelkan anak-anakmu". Tanggung jawab timbal balik yang jelas (lih. Ef. 6:4). Dalam Tafsiran Alkitab Masa Kini menjelaskan bahwa disiplin rumah tangga, seperti ditunjukkan oleh ayat 21 ini, bukanlah lagi merupakan perkara pelaksanaan yang ketat tapi masalah menghubungkan pertalian orangtua anak kepada Kristus. ${ }^{15}$ Dengan kata lain, perhatian dan kasih sayang orangtua yang lebih tekankan dalam hubungan antara orangtua dengan anak yang dibangun melalui komunikasi positif. Komunikasi yang dilakukan seharusnya diupayakan seimbang dan terbuka. Ayah dan ibu harus mampu berperan sebagai orangtua, teman, partner maupun sebagai guru privat bagi anak-anak di rumah.

\section{Pembahasan}

Anak yang berbakat membutuhkan orang tua yang responsif dan fleksibel terhadap halhal yang dikerjakan anak yang terlalu muda untuk anak seusianya. Memang suatu hal yang terlalu muda untuk anak seusianya. Tetapi kalau cara itu tidak bisa dilakukan, bisa juga dengan cara orang tua hendaknya meluangkan banyak waktu bagi anaknya supaya orang tua tahu apa minat dan bakat yang dipunyai oleh anaknya. ${ }^{16}$ Kartini Kartono mengatakan bahwa, keluarga merupakan lembaga pertama dalam kehidupan anak, tempat ia belajar dan menyatakan diri sebagai makhluk sosial. Dalam keluarga umumnya, anak adadalam hubungan interaksi yang intim.Keluarga memberikan dasar pembentukan tingkah laku, watak, moral, dan pendidikan anak. ${ }^{17}$ Joan Beck mengungkapkan, banyak proyek riset jangka lama menunjukkan bahwa intelegensi anak akan berkembang ke tingkat yang lebih tinggi, bila sikap di rumah terhadap anak, hangat dan demokratis daripada dingin dan otoritas.

Dasar hubungan kedekatan antara anak dengan orangtua diperkuat dari upaya-upaya mempertahankan kedekatan yang dilakukan oleh kedua belah pihak. Peran aktif orang tua dan interaksi dua arah yang dilakukan oleh orang tua dan anak. ${ }^{18}$ Pengaruh Ayah dalam pembentukan karakter anak, antara lain: Keteladanan. keharmonis antara suami dan istri.

\footnotetext{
${ }^{15}$ Donald Guthrie, Tafsiran Alkitab Masa Kini 3: Matius-Wahyu (Jakarta: Yayasan Komunikasi Bina Kasih/OMF, 2006), 657.

${ }^{16}$ R. Akbar Hawardi, Psikologi Perkembangan Anak: Mengenal Sifat, Bakat, Dan Kemampuan Anak (Jakarta: PT. Gramedia Widiasarana Indonesia, 2001), 23.

${ }^{17}$ Kartini Kartono, Peran Keluarga Memandu Anak (Jakarta: Rajawali Press, 1992), 19.

${ }^{18}$ Nia Andriyani and Endang Sri Indrawati, Dasar Hubungan Kedekatan Anak Dengan Orangtua Pada Mahasiswa Universitas Diponegoro Semarang (Semarang: Fakultas Psikologi Universitas Diponegoro, n.d.), 19.
} 
Misalnya soal murah hati meskipun ada perbedaan dalam hal ini, tetapi sebagai orang tua harus selalu konsisten, yaitu murah hati, dan senang membantu orang; Memenuhi kebutuhan emosional dan spiritual anak. Pada waktu anak sudah remaja mereka sangat membutuhkan pendampingan. Jika hubungan sudah dibiasakan, yaitu bahwa tempat bertanya yang pertama adalah kepada ayah, itu akan menjadi suatu hal yang sangat luar biasa dan akan menimbulkan suasana dekat dan akrab. Anak membutuhkan perhatian, kasih sayang, perlindungan, rasa aman, perilaku dan sikap positif dari orangtua. Ayah dan ibu merupakan pengambil peran utama sebagai orangtua untuk mengasuh anak-anaknya. Terutama kedekatan anak dengan ibu, karena ibunya yang mengandung, melahirkan dan menyusui.

\section{Tanggung jawab orang tua dalam hubungan keluarga.}

Orang tua memiliki pendekatan yang hangat kepada anak. ${ }^{19}$ Pola asuh orang tua dengan anak di dalam keluarga secara fungsional melibatkan sikap dan perilaku tertentu dari figur ayah dan ibu, baik secara sendiri-sendiri maupun secara bersama-sama. Sikap dan perilaku ini diwujudkan melalui hubungan orang tua dengan anak. Secara fungsional, tugas orang tua meliputi upaya mendidik, merawat, melindungi dan mengajar anak-anak agar anak dapat tumbuh dan berkembang secara optimal. ${ }^{20}$

Proses pendidikan yang berlangsung di sekolah hanya dalam waktu yang singkat dan terjadwal, sedangkan anak lebih banyak tinggal di rumah sehingga orangtua mempunyai peluang yang besar untuk memberikan motivasi, pengarahan, pengawasan dan mencarikan jalan keluar dalam memecahkan masalah yang dihadapi oleh anak. ${ }^{21}$ Pendidikan yang harus diberikan oleh orang tua kepada anaknya, tidak cukup dengan cara menyerahkan anak tersebut kepada suatu lembaga pendidikan. Tetapi lebih dari itu, orang tua haruslah menjadi guru yang terbaik bagi anak-anaknya. Orang tua yang demikian, tidak hanya mengajarkan pengetahuan (yang harus diketahui) dan menjawab pertanyaan-pertanyaan anaknya. Tetapi lebih dari itu orang tua juga harus menjadi teladan yang baik bagi anaknya. ${ }^{22}$ Sebagai orang tua yang bertanggung jawab kepada Tuhan, bagaimanapun sulitnya, hal ini harus tetap dilakukan. Mengandalkan Tuhan dan serahkan anak-anak sepenuhnya kepada Tuhan. Bersamaan dengan itu, hendaklah orang tua juga terus memperbaharui diri di dalam Tuhan.

Orang Kristen (baik orang tua maupun anak-anak) harus menangani hubungansecara berbeda karena komitmen utama mereka kepada Kristus. Pembahasan Paulus tentang hubungan yang pantas di rumah secara radikal berbeda dari norma budaya zamannya. Mike Raiter sebagaimana dikutip Maria Lidya Wenas dan I Putu Ayub Darmawan menjelaskan bahwa, dalam tradisi orang Yahudi tidak menghormati orang tua berarti juga tidak menghormati Tuhan. Itu sebabnya Paulus menekankan kembali pentingnya anak bersikap taat

\footnotetext{
${ }^{19}$ Sera Sonita, "Hubungan Antara Pola Asuh Orangtua Dengan Disiplin Siswa Di Sekolah,” Konselor: Jurnal Ilmiah Konseling 2 (2013): 174-181, http://ejournal.unp.ac.id/index.php/konselor.

${ }^{20}$ Irma Rostiana, Wilodati, and Mirna Nur Alia A, "Hubungan Pola Asuh OrangTua Dengan Motivasi Anak Untuk Bersekolah Di Kelurahan Sukagalih Kecamatan Sukajadi Kota Bandung," Jurnal Sosietas 5, no. 2 (n.d.).

${ }^{21}$ Syaiful Bahri2006 Djamarah, StrategiBelajarMengajar (Jakarta: Rineka Cipta, 2006), 17.

${ }^{22}$ Handreas Hartono, "Membentuk Karakter Kristen Pada Anak Keluarga Kristen,” KURIOS (Jurnal Teologi dan Pendidikan Agama Kristen) 2, no. 1 (2014): 62-69, www.sttpb.ac.id/e-journal/index.php/kurios.
} 
dan menghormati orang tua. ${ }^{23}$ Maksud dari disiplin ini ialah membuat anak menjadi orang dewasa Kristen, bukan menghasilkan orang yang kaku. Pendidikan etika Kristen, harus tunduk kepada kaidah positif berupa didikan dalam ajaran dan nasihat Tuhan (Ef. 6:4).

Paulus memperingatkan orang percaya untuk memperlakukan mereka yang ada di bawah mereka (istri, anak-anak, dan pembantu rumah tangga) dengan martabatdan kasih Kristen (seperti Filemon). Orang percaya adalah penatalayan Allah, bukan pemilik. Bagaimana kita memperlakukan satu sama lain dimaksudkan untuk menunjukkan zaman baru kepada dunia yang hilang. Untuk itu, sebagai orang percaya sebaiknya harus menunjukkan sikap Kristus kepada semua orang termasuk dalam kelaurga sendiri. Paulus berpesan "karena itu, sebagai orang-orang pilihan Allah yang dikuduskan dan dikasiha-Nya, kenakanlah belas kasihan kemurahan, kerendahan hati, kelemahlembutan dan kesabaran (Kol. 3:12).

Berdasarkan ayat di atas, maka sebagai dasar dalam mendisplinkan anak dalam keluarga adalah belas kasihan kemurahan, kerendahan hati, kelemahlembutan dan kesabaran. Oleh sebab itu, kekerasan bukanlah jalan satu-satunya dalam mendisiplinkan anak, karena kekerasan tidak pernah menghasilkan anak-anak menjadi lebih baik melalui kekerasan, namun yang terjadi dalam kekerasan adalah hanya kepedihan dan sakit hati. Itulah sebabnya Paulus sangat tegas mengatakan "Hendaklah perkataan Kristus diam dengan segala kekayaannya di antara kamu, sehingga kamu dengan segala hikmat mengajar dan menegur seorang akan yang lain dan sambil menyanyikan mazmur, dan pujian-pujian dan nyanyian rohani, kamu mengucapkan syukur kepada Allah (Kol. 3:16).

Dengan demikian dalam mendisiplin anak ada banyak hal yang perlu diperhatikan sebagaimana yang dipesankan oleh Paulus di ayat 16, selain itu jugaharus ada usaha untuk mendorong terjadinya perilaku yang baik kepada anak-anak. Salah satu perilaku baik yang diperlihatkan oleh orang tua kepada anak adalah mendidik dan mengasuh anak-anaknya dengan baik. Penanaman moral bagi anak tercermin dalam sikap dan prilaku orang tua sebagai teladan yang dapat dicontoh oleh anak dan segala nilai yang dikenal anak akan melekat pada orang-orang yang disenangi dan dikaguminya, dan melalui inilah salah satu proses yang ditempuh anak dalam mengenal nilai. ${ }^{24}$

Berdasarkan dari hasil penelitian yang dilakukan oleh Dwi Retno Setiati, keluarga memiliki peranan yang sangat penting dalam mengembangkan pribadi anak khususnya dalam penelitian membentuk sikap sosial dan kemandirian anak. Orang tua yang penuh perhatian dan kasih sayang selalu memberikan pendidikan tentang nilai-nilai kehidupan, baik agama maupun sosial budayanya, agar anak menjadi pribadi dan anggota masyarakat yang sehat. ${ }^{25}$ Dalam pendidikan anak, bukan hanya dilakukan oleh ibu saja atau ayah saja, akan tetapi

\footnotetext{
${ }^{23}$ Mike Raiter, Kitab Kolose Dan Filemon, Bertambah Teguh Dalam Tuhan (Jakarta: Duta Harapan Dunia, 2016), 50 .

${ }^{24}$ Nasiruddin, "Peran Keluarga, Sekolah, Dan Masyarakat Dalam Pendidikan Karakter Generasi Muda Bangsa," in Seminar Nasional Tahunan Fakultas Ilmu Sosial Universitas Negeri Medan (Medan, 2017), 339343.

${ }^{25}$ Dwi Retno Setiati, "Peran Pendidikan Keluarga Dalam Pembentukan Sikap Sosial Dan Kemandirian Anak," in Seminar Nasional Universitas PGRI Yogyakarta (Yogyakarta, 2015), 174.
} 
kedua belah pihak, baik ayah maupun ibu. Meskipun Firman Tuhan mengatakan ayah yang mendidik anak, karena memang ayahlah yang menjadi kepala keluarga yang harus bertanggung jawab, tetapi pelaksanaannya adalah dua-duanya.

Selain itu, dalam Alkitab Penuntun Hidup Berkelimpahan menguraikan beberapa tugas orangtua untuk menuntun anaknya menuju kehidupan yang saleh di dalam Kristus, yakni: Mengajar anak-anak agar takut akan Tuhan; mengajar anak-anak untuk menaati orangtua; melindungi anak-anak dari berbagai pengaruh jahat; menyadarkan anak-anak bahwa Allah selalu melihat setiap orang yang berbuat baik dan jahat; mengajar anak-anak bahwa Allah mengasihi setiap orang. ${ }^{26}$ Namun, satu hal yang tidak berubah adalah konsistensi orang tua, bahwa ayah dan ibu akan selalu menjadi model pembelajaran bagi anak-anaknya. Sikap orang tua dapat mengilhami anak-anak dan menunjukkan kepada anak bagaimana sikap bertanggung jawab atas perjalanan pendidikan dalam keluarga.

Alkitab sendiri telah memberi penjelasan berkaitan dengan cara merealisasikan disiplin dalam pendidikan anak; karena melalui kedisiplinan dapat membantu anakuntuk meraih masa depannya. ${ }^{27}$ Namun, perlu diingat bahwa tindakan keras dalam mendisiplinkan anak harus dijadikan sebagai jalan terakhir, tetapi harus disesuikan dengan persoalan yang ada, sebab tindakan keras memiliki pengaruh yang tidak terlalu besar bagi anak-anak. Hanya tindakan disiplin perlu dilaksanakan dengan mengutamakan kasih, menggunakan nasihat sebagai cara mendisiplin, mendoakan dan menyerahkan anak tersebut pada Tuhan, dan serta menjadikan tindakan pukulan sebagai jalan terakhir dalam mendisiplin. ${ }^{28}$ Selain itu orang tua menunjukkan dirinya sebagai guru kepada anak-anak termasuk dalam melatih membaca buku, membersihkan rumah dan mengatur waktu.

\section{Refleksi Kolose 3:21}

Pola pendidikan anak dalam keluarga menurut Kolose 3:21 dapat dijabarkan dalam beberapa poin berikut:

Pertama, menghentikan tindakan kekerasan. Tindakan kekerasan pada anak-anak tidak menjadi solusi terbaik dalam mendidik anak-anak. Karena kekerasan tidak pernah menghasilkan anak-anak menjadi lebih baik melalui kekerasan, namun yang terjadi dalam kekerasan adalah hanya kepedihan dan sakit hati. Meski masih kecil, anak-anak juga memiliki hati yang bisa merasa, bisa terluka. Hati yang terlanjur tawar atau mungkin sudah pahit seringkali susah untuk dipulihkan. Jangan sampai karena tidak mampu menahan emosi orangtu bertindak melewati batas dan meninggalkan luka di hati anak-anak. Oleh karena itu, salah satu solusi yang terbaik dalam mendidik anak-anak adalah orang tua memberi teguran/nasihat berdasarkan nilai-nilai Kristiani yang ada (Kol. 3:16).

\footnotetext{
${ }^{26}$ Donald Stamps, Alkitab Penuntun Hidup Berkelimpahan (Malang: Gandum Mas, 2003), 1994.

${ }^{27}$ Yushak Soesilo, "Penggunaan Rotan Dalam Pendisiplinan Anak Menurut Kitab Amsal 23:13-14," DUNAMIS ( Jurnal Teologi dan Pendidikan Kristiani ) 1, no. 1 (2016): 1-14, www.sttintheos.ac.id/ejournal/index.php/dunamis.

${ }^{28}$ Ayang Emiyati, "Mendisiplin Anak Menurut Prinsip Kristen," Evangelikal: Jurnal Teologi Injili dan Pembinaan Warga Jemaat 2, no. 2 (2018): 147-156.
} 
Sasaran utama orang tua dalam membentuk prestasi anak-anak adalah perilaku yang baik, agar anak-anak menjadi lebih dewasa dan bertanggung jawab dalam mencapai prestasi yang memuaskan di sekolah. Ada beberapa bentuk-bentuk tuntutan orangtua terhadap prestasi anak-anak, yakni: Orang tua menuntut anak untuk bertanggung jawab atas segala upaya dan capaian prestasinya; orang tua memberikan pengawasan kepada anak khususnya dalam pencapaian prestasinya, dan; orang tua menerapkan kedisiplinan kepada anak dalam usahanya mencapai prestasi. ${ }^{29}$

Kedua, kasih sayang. Kasih sayang orangtua yang lebih penting dari seribu kata atau barang-barang berharga, karena kasih sayang orangtua menjadi salah satu filter bagi anak dalam menghadapi berbagai persoalan yang ada. Makanya jangan heran jika banyak anakanak kabur dari rumah, lalu anak-anak pergi mencari kesenangan bersama dengan temanteman sebaya, ini akibat dari ketidaknyamanan dan kurangnya perhatian orang tua dalam rumah sehingga dengan sendirinya hal-hal negative pun terekspresi pada perilaku buruk anakanak itu sendiri. Kasih sayang orang tua bukanlah semata kasih sayang yang memberikan materi atau dengan menyediakan banyak fasilitas yang lengkap untuk anaknya. Tetapi kasih sayang orang tua juga dalam bentuk perhatian kepada anaknya. Jadi, mengasihi berarti mencintai dan menyayangi. Dengan rangkaian kata asah-asih-asuh, maka pengasuhan anak bertujuan untuk meningkatkan atau mengembangkan kemampuan anak dan dilakukan dengan dilandasi rasa kasih sayang tanpa pamrih.

Ketiga, orang yang bertanggung jawab. "Dan kamu, bapa-bapa, janganlah bangkitkan amarah di dalam hati anak-anakmu, tetapi didiklah mereka di dalam ajaran dan nasihat Tuhan." Seorang ayah tidak bisa meninggalkan tanggung jawab pendidikan anak dan menyerahkan seluruh aspek pendidikan kepada ibu karena dia sendiri berperanan sebagai wakil Allah dalam keluarga. Alkitab secara konsisten dari Perjanjian Lama sampai Perjanjian Baru tidak pernah mengabaikan peranan ayah dalam mendidik anak. Sementara saat ini, kebanyakan para ayah tidak mau bertanggung jawab dalam pendidikan anaknya. Inilah satu sikap yang dengan sengaja melawan kebenaran firman Tuhan. Jadi anak belajar mengenal Allah melalui figur ayah. Alkitab mengajar para ayah untuk mendidik anak dengan baik. Disinilah keindah-annya jika seorang anak boleh dilahirkan di keluarga Kristen dimana orangtua mendidiknya di dalam iman Kristen. Inilah warisan dan anugerah yang terlalu besar yang tidak mungkin dimiliki jika anak itu dilahirkan di dalam keluarga non-Kristen.

\section{Kesimpulan}

Peran orang tua dalam mendidik anak sangat penting karena orang tua adalah tempat pertama kali bagi anak untuk mendapatkan pendidikan sebelum mendapatkan pendidikan di sekolah; itulah sebabnya Paulus menyerahkan tugas dan tanggung jawab ini kepada ayah dan ibu. Namun pesan teks dalam tulisan Paulus ini lebih cenderung pada tanggung jawab seorang ayah. Seorang ayah tidak bisa meninggalkan tanggung jawab pendidikan anak dan

\footnotetext{
${ }^{29}$ Rahma Jayanti dan Iwan Wahyu Hidayat, Hubungan antarara Tuntutan Orang tua terhadap Prestasi dengan Perfeksionisme pada Anak Berbakat di SMA Negeri 1 Gresik (Jurnal Psikologi Klinis dan Kesehatan Mental Vol.03 No.3, Desember 2014), p.154
} 
menyerahkan seluruh aspek pendidikan kepada ibu karena dia sendiri berperanan sebagai wakil Allah dalam keluarga. Mendidik bukan sembarang mendidik, tetapi mendidik di dalam nasihat dan ajaran Tuhan, sesuai teks Kolose 3:21.

\section{Referensi}

A.A. Sitompul, and Ulrich Beyer. Metode Penafsiran Alkitab. Jakarta: BPK Gunung Mulia, 2009.

Andriyani, Nia, and Endang Sri Indrawati. Dasar Hubungan Kedekatan Anak Dengan Orangtua Pada Mahasiswa Universitas Diponegoro Semarang. Semarang: Fakultas Psikologi Universitas Diponegoro, n.d.

Ayang Emiyati. "Mendisiplin Anak Menurut Prinsip Kristen." Evangelikal: Jurnal Teologi Injili dan Pembinaan Warga Jemaat 2, no. 2 (2018): 147-156.

Charles E. Pfeiffer, and Everett F Harrison. The Wycliffe Bible Comentary (Tafsiran Alkitab Wycliffe). Malang: Gandum Mas, 2001.

Departemen Pendidikan Nasional. Kamus Besar Indonesia. Jakarta: Balai Pustaka, 1990.

Djamarah, Syaiful Bahri2006. StrategiBelajarMengajar. Jakarta: Rineka Cipta, 2006.

Donald Guthrie. Tafsiran Alkitab Masa Kini 3: Matius-Wahyu. Jakarta: Yayasan Komunikasi Bina Kasih/OMF, 2006.

Donald Stamps. Alkitab Penuntun Hidup Berkelimpahan. Malang: Gandum Mas, 2003.

Dwi Retno Setiati. "Peran Pendidikan Keluarga Dalam Pembentukan Sikap Sosial Dan Kemandirian Anak.” In Seminar Nasional Universitas PGRI Yogyakarta. Yogyakarta, 2015.

Hartono, Handreas. "Membentuk Karakter Kristen Pada Anak Keluarga Kristen." KURIOS (Jurnal Teologi dan Pendidikan Agama Kristen) 2, no. 1 (2014): 62-69. www.sttpb.ac.id/e-journal/index.php/kurios.

Hendra, Vitaurus. "Peran Orang Tua Dalam Menerapkan Kasih Dan Disiplin Kepada Anak Usia 2-6 Tahun Sebagai Upaya Pembentukkan Karakter." KURIOS (Jurnal Teologi dan Pendidikan Agama Kristen) 3, no. 1 (2015): 48-65. www.sttpb.ac.id/ejournal/index.php/kurios.

Hurlock, Elizabeth. Perkembangan Anak. Jakarta: Erlangga, 1978.

Ika Suwaji, and Yamin Setiawan. "Hubungan Penerimaan Orang Tua Dan Konsep Diri Dengan Motivasi Berprestasi Pada Anak Slowlearner." Jurnal Psikologi Indonesia 3, no. 3 (2014): 238-288.

Kartini Kartono. Peran Keluarga Memandu Anak. Jakarta: Rajawali Press, 1992.

Maria Lidya Wenas, and I Putu Ayub Darmawan. "Signifikansi Pendidikan Anak Dalam Perspektif Alkitab." Evangelikal: Jurnal Teologi Injili dan Pembinaan Warga Jemaat 1, no. 2 (2017). http://journal.sttsimpson.ac.id/index.php/EJTI.

Mike Raiter. Kitab Kolose Dan Filemon, Bertambah Teguh Dalam Tuhan. Jakarta: Duta Harapan Dunia, 2016.

Mulqiah, Zuraida, Eka Santi, and Dhian Ririn Lestari. "Pola Asuh Orang Tua Dengan Perkembangan Bahasa Anak Prasekolah (Usia 3-6 Tahun)." Dunia Keperawatan 5, no. 1 (2017): 61-67.

Nasiruddin. "Peran Keluarga, Sekolah, Dan Masyarakat Dalam Pendidikan Karakter Generasi Muda Bangsa." In Seminar Nasional Tahunan Fakultas Ilmu Sosial Universitas Negeri Medan, 339-343. Medan, 2017.

Pasuhuk, Novie D S. "Pendidikan Keluarga Yang Efektif." KURIOS (Jurnal Teologi dan Pendidikan Agama Kristen) 2, no. 1 (2014): 70-81. www.sttpb.ac.id/e- 
journal/index.php/kurios.

R. Akbar Hawardi. Psikologi Perkembangan Anak: Mengenal Sifat, Bakat, Dan Kemampuan Anak. Jakarta: PT. Gramedia Widiasarana Indonesia, 2001.

Rostiana, Irma, Wilodati, and Mirna Nur Alia A. "Hubungan Pola Asuh OrangTua Dengan Motivasi Anak Untuk Bersekolah Di Kelurahan Sukagalih Kecamatan Sukajadi Kota Bandung." Jurnal Sosietas 5, no. 2 (n.d.).

Selistia Minarni. "Hubungan Antara Komunikasi Interpersonal Orang Tua Dengan Perilaku Agresif Pada Remaja Anggota Geng Di Samarinda." Psikoborneo 5, no. 2 (2017): 301309.

Sera Sonita. "Hubungan Antara Pola Asuh Orangtua Dengan Disiplin Siswa Di Sekolah." Konselor: Jurnal Ilmiah Konseling 2 (2013): 174-181. http://ejournal.unp.ac.id/index.php/konselor.

Sitti Nadirah. "Peranan Pendidikan Dalam Menghindari Pergaulan Bebas Anak Usia Remaja." Musawa 9, no. 2 (2017).

Soesilo, Yushak. "Penggunaan Rotan Dalam Pendisiplinan Anak Menurut Kitab Amsal 23:13-14.” DUNAMIS ( Jurnal Teologi dan Pendidikan Kristiani ) 1, no. 1 (2016): 1-14. www.sttintheos.ac.id/e-journal/index.php/dunamis.

Sofia Retnowati, and Wahyu Widhiarso. "Peranan Keberfungsian Keluarga Pada Pemahaman Dan Pengungkapan Emosi." Jurnal Psikologi, no. 2 (2003): 91 - 104.

Susi Rio Panjaitan. "Teologi Anak Sebuah Kajian." In Anak Bersinar Bangsa Gemilang Jaringan Peduli Anaka Bangsa. Jakarta: Perkantas, 2018.

Word Analysis. "Bible Works.” Norfolk, 2006. 